\title{
POKRAJINSKI VIDIKI SONARAVNEGA RAZVOJA ZAVAROVANIH OBMOČIJ SLOVENSKIH ALP
}

\author{
Dušan Plut*
}

Izvleček

UDK 502.4(497.4 Triglavski narodni park)

Pokrajinski konflikti $v$ slovenskih Alpah so najbolj izraziti v zaščitenih območjih, zlasti v Triglavskem narodnem parku (TNP), kjer prihaja do soočanja zelo različnih interesov $v$ trikotniku varstvo okolja in narave-pokrajinska raba-gospodarski razvoj (značilen primerBohinj). Njihovo reševanje in iskanje optimalnega razvojno-okoljskega (sonaravnega) regionalnega razvoja bo $v$ prihodnje moralo izhajati tudi iz pokrajinske ranljivosti, načel trajnostnega sonaravnega razvoja in okrepljene razvojne in okoljske odgovornosti domačega prebivalstva in države.

Ključne besede: slovenske Alpe, Triglavski narodni park, zavarovana območja, sonaravni razvoj.

LANDSCAPE ASPECTS OF SUSTAINABLE DEVELOPMENT OF THE PROTECTED AREAS IN THE SLOVENIAN ALPS

\begin{abstract}
Landscape conflicts in the Slovenian Alps are most explicitly expressed in the protected areas, particularly in the Triglav National Park where most diverse interests clash together in a triangle defined with: protection of environment and nature-landscape use-economic development (a typical case: Bohinj). Their solving and search for the optimum developmentally-environmental (sustainable) regional development will have to proceed in the future, too, from the landscape vulnerability, principles of sustainable development and strengthened developmental and environmental responsibility of the locals and the state.
\end{abstract}

Key words: Slovenian Alps; Triglav National Park, protected areas; sustainable development.

\footnotetext{
* Dr., izr. prof., Oddelek za geografijo, Filozofska fakulteta, Univerza v Ljubljani, Aškerčeva cesta 2, 1000 Ljubljana, Slovenija
} 


\section{UVOD}

V okviru Slovenije pomenijo slovenske Alpe svojevrsten pokrajinski tip, z razmeroma visoko stopnjo pokrajinske občutljivosti in zmerno, a naraščajočo pokrajinsko obremenjenostjo. Kot odprt pokrajinski sistem so slovenske Alpe zaradi zemljepisnega položaja in predvidenega vstopa Slovenije v EZ zelo odvisne tudi od razvojnih in emisijskih razmer sosednjih območij. Zaradi povečanega turističnega in prometnega pomena ter postopnega prepoznavanja njihove večplastne pokrajinsko ekološke in naravovarstvene vloge se $\mathrm{v}$ zavarovanih in nezavarovanih območjih slovenskih Alp krepijo okoljski pritiski na občutljiv alpski ekosistem, hkrati pa naraščajo pokrajinska nasprotja.

\section{ALPE - MED RAZVOJEM IN VAROVANJEM}

Alpske pokrajine Evrope so ujete $\mathrm{v}$ globalno mrežo uniformirane tržnosti, povečevanja prostega časa in prevlade cestnega prometa, hkrati pa se prepoznava njihva nenadomestljiva neproizvodna vloga. Obstoječe, prevladujoče oblike pokrajinske rabe so nesonaravne, torej pretežno neprilagojene, neuravnotežene $\mathrm{z}$ omejeno nosilno zmogljivostjo alpskih vzpetin in dolinsko-kotlinskih pokrajinskih tipov.

Broggi (1998a, str. 120) ugotavlja, da grozi alpski pokrajini velika sprememba v času ene ali dveh generacij. Zdi se, da temu procesu še ne namenjamo dovolj pozornosti. Zastavlja se nekaj temeljnih vprašanj:

1) bo alpski svet prihodnosti izseljen in območje divjine;

2) vprašanje ohranjanja in preživetja alpskega kmetijstva, zlasti na večjih površinah;

3) vprašanje stroškov negovanja pokrajine (ali bodo večji stroški bremenili vse ali le turizem)

V občutljivem alpskem pokrajinskem ekosistemu bi morala biti ospredju naslednja temeljna sonaravna načela (Toedter, 1997, str. 134):

a) uravnoteženost gospodarskih, družbenih in okoljskih vidikov;

b) trajnostna raba naravnih virov;

c) obremenjevanja okolja v okviru zmogljivosti ekosistemov;

d) ohranjanje biotske (in pokrajinske) raznovrstnosti.

Evropski skupni trg in uresničitev novega svetovnega trgovinskega reda GATT/WTO bosta po mnenju Broggija (1998a, str. 120) vodila k povečanim obremenitvam okolja. Tudi Slovenija je postala pridružena članice EZ in želi postati polnopravna, hkrati pa 
je podpisnica Alpske konvencije. Zato je eksistenčno zainteresirana za skupne akcije zmanjšanja obremenjevanja alpskega okolja in iskanja alpskemu okolju primernejše ter trajnejše oblike pokrajinske rabe. Pojavljajo se različni predlogi bodočega gospodarskega in naravovarstvenega modela alpske pokrajinske rabe, ki jih lahko ponazorimo s dvema skrajnostima »delovati - opustiti«.

\section{POKRAJINSKI KONFLIKTI V ZAVAROVANIH OBMOČJIH SLOVENSKIH}

\section{ALP}

Tudi za slovenske Alpe velja, da se je v zadnjih nekaj desetletjih bistveno spremenil osnovni vzorec pokrajinske rabe. Spremenile so se tradicionalne oblike pokrajinske rabe, kar zlasti velja za kmetijstvo, hkrati so se pojavile nove, npr. turističnorekreativne dejavnosti. Okoljske posledice spremenjenega pokrajinskega vzorca rabe V slovenskih Alpah so večplastne, praviloma pa negativne oziroma nesonaravne. Spremenjena pokrajinska raba je hkrati povečala pokrajinsko ranljivost, pa tudi porabo naravnih virov. Sočasno potekajoči proces izseljevanja in zaraščanja visokogorske kulturne pokrajine zato ne more vzpostaviti pokrajinsko ekološko ravnovesnega stanja. Ker je ogrožena tako biotska kot pokrajinska sestava, niso zagotovljeni osnovni pogoji za trajnostni sonaravni razvoj, ki vključuje tudi mrežo zavarovanih območij. Ker tudi pri nas še niso ovrednotene netržne funkcije alpskega ekosistema in $\mathrm{v}$ njegovem okviru še posebej netržne (okoljske, kulturne) in vodnooskrbne funkcije zavarovanih območij, prihaja do nespoštovanja varstvenih režimov in netrajnostno zasnovanih dejavnosti. To velja tudi za naš edini nacionalni park, Triglavski narodni park, katerega ustanovitelj je država.

Za objektivnejšo ocenjevanje dosežene stopnje sonaravnosti se postopoma oblikujejo t.i. kazalci (indikatorji) sonaravnega razvoja (Indicators of Sustainable..., 1997). Za ožje pojmovano varstvo okolja in narave je bila v EZ po metodologiji Komisije OZN za sonaravni razvoj preizkušen niz kazalcev sonaravnega razvoja. Raziskava kaže, da so $\mathrm{z}$ vidika ohranjanja narave za slovenske razmere zlasti pomembni naslednji predlagani kazalci sonaravnega razvoja: delež zavarovanih območij, delež ogroženih vrst, sprememba pokrajinske rabe, spremembe gozdnih površin in posredno tudi delež sredstev za varstvo okolja v okviru celotnega BDP. Delež zavarovanih območij kaže na namen ohranjanja divjine, ekosistemov in naravnih virov. Kazalec je v neposredni povezavi s pripravljenostjo države, da zaščiti in ohranja naravne vire, ki kot sestavine pokrajinskega ekosistema opravljajo niz ekoloških, družbeno-gospodarskih in kulturnih funkcij. Ta kazalec sonaravnega razvoja pomeni odgovor družbe glede zaščite biotske in pokrajinske raznovrstnosti. Vendar nam navedeni kazalec ne daje informacij o resnični stopnji zavarovanja različnih območij, torej spoštovanja varstvenih režimov. 
V EZ je bilo sredi devetdesetih let zavarovanega 11,3 \% skupnih površin, v povprečju je bil ta delež večji pri severnih državah (Indicators of Sustainable..., 1997, str. 102). Več kot 20 \% zavarovanih površin od skupne površine države je bilo na Danskem $(32,2 \%)$, Nemčiji $(25,8 \%)$, Avstriji $(23,9 \%)$ in Veliki Britaniji $(20,3)$. V Sloveniji je po naravovarstveni zakonodaji na državni in občinski ravni zavarovanih približno 8 $\%$ ozemlja. Slovenija ima torej v povprečju za več kot četrtino manj zavarovanih območij, manjši delež kot Slovenija pa imajo naslednje države EZ: Belgija, Grčija, Irska, Italija, Portugalska in Švedska.

Tudi za alpske države velja, da je v višjih legah sorazmerno veliko obsežnejših varovanih površin. $\mathrm{V}$ alpskih območjih je namreč zaradi manjše gostote poseljenosti manj pokrajinskih nasprotij. Tako je bila na začetku devetdesetih let gostota prebivalstva $\mathrm{v}$ alpskem delu Slovenije, Italije in Avstrije bistveno manjša kot $\mathrm{v}$ drugih območjih navedenih držav. V slovenskih Alpah, ki po alpski konvenciji po katastrskih občinah obsegajo 7336 km2, je leta 1991 živelo 72 prebivalcev/km2, kar je $\mathrm{v}$ okviru povprečja za celotne Alpe (71 prebivalcev/ $\mathrm{km} 2)$ in bistveno pod povprečjem za celotno državo (98 prebivalcev/km2). Z vidika varstva okolja in narave ter pritiskov na alpske ekosisteme je manjša gostota prebivalstva kazalec nekoliko manjših obremenitev. Gledano v celoti se je v slovenskih Alpah v obdobju 1971-1991 število prebivalcev v primerjavi z avstrijskimi in italijanskimi Alpami najbolj povečalo, saj je indeks prebivalstvene rasti bil 118. Vendar podrobnejša členitev kaže, da se je število prebivalcev povečalo v dolinah in kotlinah, hkrati pa zmanjšalo v višjem svetu, ki obsega večino površja slovenskih Alp. Žal ni podatkov o gibanju pozidanih površin, vendar ni nobenega dvoma, da beležimo tudi $v$ zadnjih dvajsetih letih prirast pozidanih neto površin. Le-te so se povečale najmanj $\mathrm{v}$ sorazmerju s povečanjem števila prebivalce, relativno pa vsaj za petino (gradnja hiš, garaž, počitniških hiš, turističnih objektov, cest itd.).

Površina slovenskih Alp po Alpski konvenciji na podlagi katastrskih občin je 7336 $\mathrm{km} 2$, kar pomeni dobro tretjino (36,2 \%) ozemlja države (preglednica 2). V slovenskih Alpah je zavarovanega $1186 \mathrm{~km} 2$ ozemlja oziroma 14,3 \% površin, kar je nekoliko manj kot v Italiji (15,6\%) in bistveno manj kot v Avstriji (29,6 \%). Vendar je treba upoštevati, da obsega kar $71 \%$ zavarovanih območij slovenskih Alp edini narodni park - Triglavski narodni park (TNP), ki meri $838 \mathrm{~km} 2$. Poleg tega obstaja še 19 območij zaščite narave in 8 pokrajinskih parkov (Broggi, 1998b). V Avstriji pa je največji delež zavarovanih alpskih območij v okviru zaščitenih krajinskih območij, $v$ Italiji pa je približno večji delež zavarovanih območij regionalnih parkov (Broggi, 1998b, str. 396). Zavarovana območja slovenskih Alp pa predstavljajo kar $89 \%$ vseh zavarovanih površin države, kar na eni strani poudarja izjemen naravovarstveni pomen slovenskih Alp, a hkrati glede na pokrajinsko pestrost Slovenije veliko neravnovesje. 
Preglednica 1: Zavarovana območja $\mathrm{v}$ avstrijskih, italijanskih in slovenskih Alpah (sreda devetdesetih let)

\begin{tabular}{|c|c|c|c|c|c|}
\hline Država & 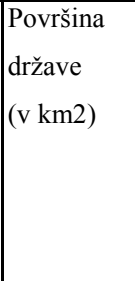 & $\begin{array}{l}\text { Površina Alp (v } \\
\text { km2) po } \\
\text { omejitvi Alpske } \\
\text { konvencije- } \\
\text { \% od vseh } \\
\text { površin }\end{array}$ & $\begin{array}{l}\text { Površine } \\
\text { zavarovanih } \\
\text { območij države (v } \\
\text { km2)-\% od vseh } \\
\text { površin }\end{array}$ & $\begin{array}{l}\text { Površine zavarovanih } \\
\text { območij Alp } \\
\text { (v km2)-\% od vseh } \\
\text { površin Alp v državi }\end{array}$ & $\begin{array}{l}\text { Delež zavarovanih } \\
\text { območij Alp od vseh } \\
\text { zavarovanih površin } \\
(\mathrm{v} \%)\end{array}$ \\
\hline Avstrija & 83853 & $\begin{array}{c}54946 \\
(65,2 \%)\end{array}$ & $\begin{array}{c}20326 \\
(24,2 \%)\end{array}$ & $\begin{array}{c}16248 \\
(29,6 \%)\end{array}$ & 79,9 \\
\hline Italija & 301268 & $\begin{array}{c}52352 \\
(17,4 \%)\end{array}$ & $\begin{array}{c}32881 \\
(10,9 \%)\end{array}$ & $\begin{array}{c}8163 \\
(15,6 \%)\end{array}$ & 24,8 \\
\hline Slovenija & 20256 & $\begin{array}{c}7336^{*} \\
(36,2 \%) \\
(6866)^{* *}\end{array}$ & $\begin{array}{c}1186 * * * \\
(5,9 \% ; 8 \%)\end{array}$ & $\begin{array}{c}1051 \\
(14,3 \%)\end{array}$ & 89,00 \\
\hline
\end{tabular}

*površina po alpski konvenciji (na podlagi kat. občin)

** površina na podlagi novih občin

*** površine narodnega parka, regionalnih parkov in krajinskih zavarovanih območij Vir: 1. poročilo o Alpah, 1998, Zakon o ohranjanju narave (osnutek), 1998.

Finančne obveznosti državnega proračuna $\mathrm{v}$ primeru celovite uresničitve novega zakona o ohranjanju narave in ustanovitve večjega števila naravnih parkov, s katerimi bi zajeli 25-30 \% državnega ozemlja, bi znašale približno 1,5 milijarde SIT. Za leto 1998 je $\mathrm{v}$ ta namen zagotovljenih v državnem proračunu 330000 SIT (Zakon o ..., 1998, str. 15).

Matrični prikaz vpliv dejavnosti in pokrajinske rabe na naravo in okolje $\mathrm{v}$ TNP opozarja na številne oblike nesonaravne dejavnosti $\mathrm{v}$ posameznih delih robnega in tudi osrednjega zavarovanega območja (Preglednica 2). Onesnaževanje okolja v TNP povzročajo točkasti, linijski in ploskovni viri zelo različnih dejavnosti (Varstvo naravne in ..., 1992, str. 17):

1) dejanski viri onesnaževanja $v$ parku: človekove dejavnosti, ki izkoriščajo domače naravne vire- ribolov, lov, gozdarstvo, kmetijstvo, energetika, turizem; prometlokalni in prehodni; naselja oziroma poselitev-trajna in začasna;

2) spreminjanje naravnega ekosistema zaradi drugih vplivov človeka oziroma rabe npr. paša, izkoriščanje gozdov, gnojenje, vodne regulacije;

3) zunanji viri onesnaževanja parka-čezmejne emisije, odpadne vode.

Zaradi človekovega vpliva so v TNP prizadeti vsi elementi naravnega okolja, praviloma $\mathrm{v}$ manjših območjih $\mathrm{v}$ približno ci vira onesnaževanja ali v območju, kjer posamezna človekova dejavnost poteka. V gorskem svetu je vplivov sorazmerno 
Preglednica 2: Vpliv dejavnosti in pokrajinske rabe na naravo in okolje v TNP (sreda devetdesetih let)

\begin{tabular}{|c|c|c|c|c|c|c|c|c|c|c|c|}
\hline 1 & 2 & 3 & 4 & 5 & 6 & 7 & 8 & 9 & 10 & 11 & 12 \\
\hline LOV & & & & & & & & 0 & 0 & 0 & \\
\hline \multicolumn{12}{|l|}{ RIBOLOV } \\
\hline Ribolov & & & & & & & & 0 & & 0 & \\
\hline Ribogojnice & 0 & 0 & & & & & & 0 & & 0 & \\
\hline \multicolumn{12}{|l|}{ GOZDARSTVO } \\
\hline Gos. raba gozda & & & & & 0 & 0 & 0 & 0 & & & \\
\hline Gozdna mehan. & & & $*$ & & 0 & 0 & 0 & 0 & 0 & 0 & 0 \\
\hline Gozdne promet. & & & + & & 0 & 0 & 0 & 0 & + & & \\
\hline \multicolumn{12}{|l|}{ KMETIJSTVO } \\
\hline Obdelava, paša & & & & & & 0 & 0 & 0 & & & \\
\hline Agromelioracije & 0 & 0 & 0 & & 0 & 0 & 0 & + & + & & \\
\hline Gnojenje & 0 & 0 & 0 & & & 0 & 0 & 0 & 0 & & \\
\hline Hlevi & & & $*$ & & & 0 & & & 0 & & 0 \\
\hline Kmet. mehaniz. & & & $*$ & & 0 & & & & 0 & 0 & \\
\hline Kmet. promet & & & & & 0 & 0 & 0 & + & + & & \\
\hline VODNO GOSP. & 0 & & 0 & & 0 & & 0 & 0 & + & + & \\
\hline \multicolumn{12}{|l|}{ POSELITEV } \\
\hline Stalna naselja & 0 & 0 & 0 & 0 & 0 & 0 & 0 & 0 & 0 & 0 & 0 \\
\hline Počit. hiše & 0 & 0 & 0 & 0 & 0 & 0 & 0 & 0 & 0 & 0 & 0 \\
\hline \multicolumn{12}{|l|}{ PROMET } \\
\hline Motorni & 0 & $*$ & $*$ & 0 & 0 & 0 & 0 & 0 & 0 & 0 & 0 \\
\hline Letalski & & & $*$ & 0 & & & 0 & & 0 & & 0 \\
\hline Prometnice & & & $*_{+}$ & & 0 & 0 & 0 & + & + & 0 & + \\
\hline \multicolumn{12}{|l|}{ TURIZEM } \\
\hline Turisti,obiskov. & & & & & & & 0 & 0 & 0 & 0 & 0 \\
\hline Planinci & & & & & 0 & & 0 & 0 & 0 & 0 & \\
\hline Kopalci & & 0 & & & & & 0 & 0 & 0 & 0 & 0 \\
\hline Smučarji & & & & & & & 0 & 0 & & 0 & \\
\hline Hoteli, kampi & 0 & 0 & 0 & 0 & & & & & & 0 & \\
\hline Planinske koče & & 0 & $0 *$ & & & & & & 0 & 0 & \\
\hline Smuč. Naprave, Mehanizacija & & & $*$ & 0 & 0 & 0 & 0 & 0 & 0 & 0 & \\
\hline \multicolumn{12}{|l|}{ ENERGETIKA } \\
\hline MHE & 0 & & & & 0 & & & 0 & + & & \\
\hline Dizel agregati & & & $*$ & 0 & & & & & 0 & & 0 \\
\hline
\end{tabular}

Legenda:

$0=$ vpliv na naravo, obremenjevanje $*=$ možnost onesnaževanja $\quad+=$ vpliv v času gradnje

1 Dejavnost, pokrajinska raba

4 Podzemeljska voda

2 Tekoča voda

3 Jezero

7 Prst

5 Zrak

6 Relief

10 Hrup

8 Vegetacija

9 Živalstvo

Vir: Urbanistični inštitut RS, Uprava TNP, 1992.

12 Nevarnost požara 
malo, povzročajo pa jo predvsem promet, turizem in rekreacija. Številni in obsežni pa so vplivi v dolinskem svetu (kmetijstvo, ribolov, poselitev, promet, turizem in rekreacija) (Varstvo naravne in ..., 1992, str. 17). Pokrajinska nasprotja med varovanjem narave ter naravnih virov in obstoječim modelom bivanja in dela so najbolj izrazita $\mathrm{v}$ turizmu in rekreacijskih dejavnostih (smučišča, kampi, hoteli, počitniške hiše, planinske koče itd.) in cestnem prometu (vključno s naraščajočim osebnim motoriziranim prometom na gozdnih cestah). Vse bolj pereče so zlasti količine odpadnih vod, nastalih iz fekalij, kuhinjskih odtokov in pralnih strojev v planinskih postojankah, počitniških hišah in domovih, ostankov mineralnih gnojil s pašnikov itd (Bizjak, 1997). Odpadne vode presegajo samočistilne sposobnosti apniških Julijskih Alp, zato je zelo potrebna nadaljnja dejavnost npr. za zmanjšanje odpadnih voda iz planinskih postojank, ki jih je v TNP 44 (iz pralnic, stranišč in kuhinj).

Vode, ki izvirajo v TNP, predstavljajo $20 \%$ vodnega potenciala Slovenije.V zadnjem desetletju je TNP postal cilj mnogih, ki gojijo alternativne oblike športne rekreacije. Gorski kolesarji, jadralni padalci, soteskarji in podobni so nova, dodatna obremenitev okolja, ki bi morala biti prostorsko in časovno urejena (Šolar, 1997).

Težave pri financiranju, delovanju in izvajanju varstvenih režimov celo $\mathrm{v}$ našem edinem narodnem parku so dovolj jasno opozorilo, da smo pri varovanju narave in prilagajanju mednarodnim kategorijam zavarovanja (IUCN) še zelo oddaljeni od zaželenega ravnanja. Nerazumljiva je predvsem popustljivost države do črnograditeljev na območju TNP.

\section{GEOGRAFSKE SMERNICE SONARAVNEGA RAZVOJA SLOVENSKIH} ALP

Potrebo po (trajnostno) sonaravnem razvoju slovenskih Alp pogojujejo naslednje značilnosti alpskega pokrajinskega ekosistema:

1) geomorfološka dvojnost in $\mathrm{s}$ tem povezana različna občutljivost alpskega ekosistema (vzpeti svet in dolinsko ravninsko območje);

2) večja nadmorska višina in naklon zemljišč ter s tem povezana velika reliefna energija,

3) prevlada kraških padavin in kraške hidrogeografije;

4) izrazita pokrajinska občutljivost alpskega sveta nad gozdno mejo;

5) pretežno skromnejše možnosti za preprečitev vnosa škodljivih snovi v pokrajinotvorne sestavine (zlasti v vodo in prst);

6) odprtost oziroma občutljivost alpskega pokrajinskega ekosistema na zunanje okoljske pritiske; 
7) pokrajinska dvojnost (doline - vzpeti svet) $\mathrm{z}$ različno pokrajinsko ranljivostjo in pritiski na okolje ter naravo;

8) nekonkurenčnost kmetijskih pridelkov (težje pridelovalne razmere) intenzivnega kmetijstva;

9) velika pokrajinska občutljivost na intenzivne oblike turizma in motoriziran cestni promet (osebni, tovorni);

10) naraščajoča reproduktivna, okoljska, netržna vloga alpskega ekosistema (pokrajinsko izravnalna, biotska).

Temeljna načela trajnostne pokrajinske rabe robnih zavarovanih območij TNP in bodočih regijskih parkov bi morala ustrezati sledečim okoljsko zasnovanim zahtevam (načela »zmerne« sonaravnosti):

- $\quad$ obnovljive vire je možno črpati le toliko, kolikor jih je možno obnoviti (prst, gozd,voda, ribolov);

- minimizacija rabe neobnovljivih naravnih virov (gradbeni material);

- okolje je dovoljeno obremenjevati z emisijami, odpadki in odplakami le toliko, kolikor jih lahko razgradimo (stanje okolja - zrak, voda, gozd itd, odnos občutljivost - obremenjevanje);

- pokrajinska raba mora zagotavljati ohranjanje pokrajinske in biotske pestrosti.

Temeljna načela trajnostne pokrajinske rabe osrednjih zavarovanih območij (načela "močne« sonaravnosti):

- neobnovljivih naravnih virov ni mogoče uporabljati;

- $\quad$ v dinamiko naravnih procesov in pokrajinske sestavine ni mogoče posegati razen izjemoma na območjih kulturne pokrajine;

- $\quad$ v dinamiko razvoja populacij živalskih vrst ni mogoče posegati.

Pokrajinske značilnosti in spremembe pokrajinske rabe pojezerja Bohinjskega jezera in samega jezera so primeren kazalec stopnje (ne)sonaravnega razvoja in sprememb okoljskih pritiskov v zavarovanih območij slovenskih Alp oziroma območja TNP. Bohinjsko jezero je še vedno razmeroma čisto, delno urejena kanalizacija, kmetijstvo in promet ob jezeru pa so glavni onesnaževalci jezerske vode (Remec Rekar, 1996; Šnuderl, 1998). Razvoj približno ce Bohinjskega jezera je eksistenčno odvisen od usklajevanja razvoja turizma z varovanjem okolja (Šnuderl, 1998). Osnovni cilji sonaravnega razvoja so varovanje okolja, ohranjanje kulturne pokrajine ter omogočanje razvoja turizma. Dolgoročna gospodarska uspešnost območja ob jezeru je odvisna od kakovosti in trajnosti turističnega proizvoda, ki pa ga je možno dosegati le $\mathrm{z}$ varovalnim gospodarskim razvojem turističnega gospodarstva $\mathrm{v}$ bohinjskemu krajinskemu prostoru (Hočevar, Ogulin s sod., 1995 , str. 1). 
Okviren predlog temeljnih sonaravnih ukrepov na podlagi pokrajinske zmogljivosti je za Bohinj naslednji:

- zmanjšanje turistične in prometne obremenitve zahodnega roba Bohinjskega jezera $\mathrm{s}$ premeščanjem in zgostitvijo turistične dejavnosti in poselitve na vzhodnem robu Bohinjskega jezera, zunaj pojezerja (npr. premestitev avtokampa);

- čimprejšnje dokončanje izgradnje kanalizacijskega omrežja Ukanc in sistema čiščenja odpadnih vod, pospešeno zmanjševanje odpadnih voda planinskih postojank v pojezerju;

- bistveno zmanjšanje in omejitve gostote osebnega motornega prometa ob jezeru, organizacija javnega prometa (najprej poleti), povezana mreža sprehajalnih poti;

- $\quad$ spodbude za ohranjanje deleža kulturne pokrajine in za preusmejanje na biološko kmetijstvo, zlasti v pojezerju (problem gnojenja);

- povezovanje sonaravnega kmetijstva, sonaravnega turizma in zemljepisne lege $\mathrm{v}$ TNP s trženjem blagovne znamke »Bohinj - TNP«;

- posodobitev zakona o TNP, povečanje državnih proračunskih sredstev za zavarovana območja in podpora sonaravnim oblikam gospodarjenja ter bivanja.

\begin{abstract}
SKLEP
Slovenske Alpe in njeni prebivalci se pri iskanju okolju in ljudem primernejšega modela regionalnega razvoja še bolj kot ostala območja soočajo s številnimi razvojnimi in pokrajinskimi vprašanji. Pokrajinski konflikti med porabniki prostora so najbolj izraziti v zaščitenih območjih, zlasti v Triglavskem narodnem parku (TNP), kjer prihaja do soočanja zelo različnih interesov v trikotniku: varstvo okolja in narave-pokrajinska raba-gospodarski razvoj (značilen primer - Bohinj).

Njihovo reševanje in iskanje optimalnega razvojno-okoljskega (sonaravnega) regionalnega razvoja bo $\mathrm{v}$ prihodnje moralo izhajati tudi iz pokrajinske ranljivosti, doslednega spoštovanja načel trajnostnega sonaravnega razvoja in okrepljene razvojne in okoljske odgovornosti domačega prebivalstva ter države. Samo v primeru zadovoljivih rešitev v našem edinem narodnem parku (TNP) lahko pričakujemo zlasti z dolgoročnega slovenskega (državnega) in evropskega interesa potrebno širjenje alpskih (in izven alpskih) zavarovanih območij (zlasti regionalnih parkov) na najmanj $20 \%(30 \%)$ ozemlja. V Sloveniji pa se tudi v zavarovanih območjih alpskega sveta zaradi denacionalizacije delež javnih površin zmanjšuje, kar bo verjetno otežilo zagotavljanje spoštovanja strogih varstvenih režimov. Nacionalne koristi bo treba zavarovati s strogimi omejitvami oziroma prepovedjo pridobivanja lastninske pravice do nepremičnin za tujce $v$ zavarovanih območjih.

Ohranjanje pokrajinske in biotske pestrosti slovenskih Alp bo torej tesno odvisno od zmanjševanja domačih in tujih emisij, okolju prilagojenega gospodarjenja z naravnimi
\end{abstract}


viri in hkrati od uspešnosti razširjene mreže zavarovanih območij ter sonaravnejšega vzorca pokrajinske rabe $\mathrm{v}$ zavarovanih (močna sonaravnost) in nezavarovanih območjih (šibka sonaravnost).

\section{LITERATURA}

1) Bizjak J., 1997: Okoljevarstvene dileme v Triglavskem narodnem parku - kako naprej, Razprave in raziskave 6, Bled, $7-11$.

2) Broggi M., 1998a: Ukrepati ali opazovati - štiri teze o ravnanju v alpskem prostoru, 1. Poročilo o Alpah (prevod), CIPRA, Založba Grafiti studio, Maribor, $120-124$.

3) Broggi M., 1998b: Podatki o naravi in pokrajini, 1. poročilo o Alpah (prevod), CIPRA, Založba Grafiti studio, Maribor, 377 - 393.

4) Hočevar M in sod., 1995: Kamp Ukanc v Bohinju - ocena vplivov na okolje in variantni predlogi za dolgoročno reševanje problemov obalnega območja Bohinjskega jezera (raziskovalni projekt), Gozdarski inštitut Slovenije, 73.

5) Indicators of Sustainable Development, 1997, Eurostat - European Communities, Luxembourg, 126.

6) Plut D., 1996: Naravni parki in pokrajinska pestrost Slovenije, Zbornik Vrt Evrope, Liberalna akademija in Ekološki forum LDS, Ljubljana, 25 - 30.

7) Remec Rekar Š., 1996: Življenje jezer: čisti jezeri - ponos Bleda in Bohinja, Gorenjski tisk, Kranj, 34.

8) Šnuderl K., 1998: Strokovne osnove za zasnovo celovitega koncepta razvoja približno ce Bohinjskega jezera (diplomska naloga), Oddelek za geografijo Filozofske fakultete, Ljubljana, 74.

9) Šolar M., 1997: Gorniška dejavnost v Triglavskem narodnem parku, razprave in raziskave 6 , Bled, $13-21$.

10) Toedter U., 1997: Trajnostno gospodarjenje v Alpah - pogled v prihodnost, 1. Poročilo o Alpah (prevod), CIPRA, Založba Grafiti studio, Maribor, 120 - 124.

11) Varstvo naravne in kulturne krajine V Triglavskem narodnem parku, 1992, Strokovna knjižnica TNP-razprave in raziskave 1, Bled, 78.

12) Zakon o ohranjanju narave (predlog), 1998, Ministrstvo za okolje in prostor RS, Ljubljana, 111. 


\section{POKRAJINSKI VIDIKI SONARAVNEGA RAZVOJA ZAVAROVANIH OBMOČIJ SLOVENSKIH ALP}

\section{Povzetek}

Alpske pokrajine so ujete $\mathrm{v}$ globalno mrežo uniformirane tržnosti, povečevanja prostega časa in prevlade cestnega prometa, hkrati pa se prepoznava njihova nenadomestljiva neproizvodna vloga. Obstoječe, prevladujoče oblike pokrajinske rabe so nesonaravne, torej pretežno neprilagojene, neuravnotežene $\mathrm{z}$ omejeno nosilno zmogljivostjo alpskih vzpetin in dolinsko - kotlinskih pokrajinskih tipov.

Tudi za slovenske Alpe velja, da se je v zadnjih nekaj desetletjih bistveno spremenil osnovni vzorec pokrajinske rabe. Spremenile so se tradicionalne oblike pokrajinske rabe, kar zlasti velja za kmetijstvo, hkrati so se pojavile nove, zlasti turistično rekreativne dejavnosti. Okoljske posledice spremenjenega pokrajinskega vzorca rabe v slovenskih alpah so večplastne, praviloma pa negativne oziroma nesonaravne. Spremenjena pokrajinska raba je hkrati povečala pokrajinsko občutljivost in pokrajinsko obremenjenost, pa tudi porabo naravnih virov. Sočasno potekajoč proces izseljevanja in zaraščanja visokogorske kulturne pokrajine ne more vzpostaviti pokrajinsko ekološko ravnovesnega stanja. Ob hkratnem povečanem vnosu obremenjevanja (zračnemu) okolja iz sosednjih pokrajin se je dodatno okrepil okoljski pritisk. Ker je ogrožena tako biotska kot pokrajinska sestava, niso seveda izpolnjeni osnovni pogoji za trajnostni sonaravni razvoj, ki vključuje tudi mrežo zavarovanih območij.

Zavarovana območja slovenskih Alp predstavljajo kar 89 \% vseh zavarovanih površin države. Velik delež na eni strani podčrtuje izjemen naravovarstveni pomen slovenskih Alp, a hkrati predstavlja glede na pokrajinsko pestrost Slovenije ekosistemsko neravnovesje. Hkrati so pokrajinski konflikti najbolj izraziti v zaščitenih območjih, zlasti v Triglavskem narodnem parku (TNP), kjer prihaja do soočanja zelo različnih interesov $\mathrm{v}$ trikotniku varstvo okolja in narave-pokrajinska raba-gospodarski razvoj (značilen primer-Bohinj).

Njihovo reševanje in iskanje optimalnega razvojno-okoljskega (sonaravnega) regionalnega razvoja bo $\mathrm{v}$ prihodnje moralo izhajati tudi iz pokrajinske ranljivosti, načel trajnostnega sonaravnega razvoja in okrepljene razvojne in okoljske odgovornosti domačega prebivalstva in države. 